\title{
Naturally acquired antibodies to merozoite surface protein (MSP)-1 19 and cumulative exposure to Plasmodium falciparum and Plasmodium vivax in remote populations of the Amazon Basin of Brazil
}

\author{
Simone Ladeia-Andrade/ ${ }^{+}$, Marcelo Urbano Ferreira*, Kézia Katiani Gorza Scopel**, \\ Érika Martins Braga**, Melissa da Silva Bastos*, Gerhard Wunderlich*, José Rodrigues Coura
}

\author{
Laboratório de Doenças Parasitárias, Instituto Oswaldo Cruz-Fiocruz, Av. Brasil 4365, 21045-900 Rio de Janeiro, Brasil \\ *Departamento de Parasitologia, Instituto de Ciências Biomédicas, Universidade de São Paulo, São Paulo, Brasil **Departmento de \\ Parasitologia, Instituto de Ciências Biomédicas, Universidade Federal de Minas Gerais, Belo Horizonte, Brasil
}

To infer recent patterns of malaria transmission, we measured naturally acquired $\operatorname{Ig} G$ antibodies to the conserved 19-kDa C-terminal region of the merozoite surface protein (MSP)-1 of both Plasmodium vivax (PvMSP-1 19$)$ and Plasmodium falciparum (PfMSP-1 19 ) in remote malaria-exposed populations of the Amazon Basin. Community-based cross-sectional surveys were carried out between 2002 and 2003 in subjects of all age groups living along the margins of the Unini and Jaú rivers, Northwestern Brazil. We found high prevalence rates of IgG antibodies to PvMSP-1 19 (64.0 - 69.6\%) and PfMSP-1 19 (51.6 - 52.0\%), with significant differences in the proportion of subjects with antibodies to PvMSP-1 19 according to age, place of residence and habitual involvement in high-risk activities, defining some groups of highly exposed people who might be preferential targets of malaria control measures. In contrast, no risk factor other than age was significantly associated with seropositivity to PfMSP-1 ${ }_{19}$. Only $14.1 \%$ and $19.3 \%$ of the subjects tested for antibodies to PvMSP-1 ${ }_{19}$ and PfMSP-1 19 in consecutive surveys (142 - 203 days apart) seroconverted or had a three fold or higher increase in the levels of antibodies to these antigens. We discuss the extent to which serological data correlated with the classical malariometric indices and morbidity indicators measured in the studied population at the time of the seroprevalence surveys and highlight some limitations of serological data for epidemiological inference.

Key words: malaria - Amazon - merozoite surface protein-1 - transmission rates

Antigens expressed on the surface of asexual bloodstage malaria parasites are major targets of antibodies elicited by exposure to infection. One of the best characterized surface antigens is the merozoite surface protein (MSP)-1, a 185-210 $\mathrm{kDa}$ polymorphic protein synthesized during late schizogony (Blackman et al. 1990). MSP- $1_{19}$, the $19-\mathrm{kDa}$ C-terminal product of secondary enzymatic processing of MSP-1, is the only fragment of this protein that remains anchored to the merozoite surface at the time of erythrocyte invasion (Blackman et al. 1991). MSP- $1_{19}$ has two cysteine-rich domains, analogous to epidermal growth factor motifs, which are putatively required in interactions with erythrocytes (Blackman et al. 1991, Han et al. 2004). The C-terminal region of MSP-1 is fairly conserved in both Plasmodium falciparum (Tanabe et al. 1987, Miller et al. 1993, Ferreira et al. 2003) and Plasmodium vivax (Soares et al. 1999a, Putaporntip et al. 2002), but the sequence divergence ( $46 \%$ aminoacid mismatch) between the

Financial support: CAPES, CNPq, PAPES-Fiocruz +Corresponding author: sladeia@ioc.fiocruz.br

Received 19 July 2007

Accepted 18 December 2007
MSP- $1_{19}$ homologs of $P$. falciparum and $P$. vivax (del Portillo et al. 1991) is large enough to prevent significant cross-recognition between-species.

MSP- $1_{19}$ is a major target of naturally acquired human antibodies that inhibit erythrocyte invasion by merozoites in vitro (O'Donnell et al. 2001). In addition, levels of naturally acquired anti-P. falciparum (PfMSP1 ${ }_{19}$ ) antibodies measured with conventional enzyme-liked immunosolvent assay (ELISA) have been positively associated with protection from $P$. falciparum infections in some (Egan et al. 1996, Branch et al. 2000), although not all (Dodoo et al. 1999, Riley et al. 2000) African cohorts. In Brazil, there is evidence from cross-sectional studies of an association between levels of antibodies to $\mathrm{MSP}-1_{19}$ and reduced risk of clinical malaria (Braga et al. 2002). However, it remains unknown whether all antibodies to PfMSP- ${ }_{19}$ detected by ELISA are functionally relevant. A recent cohort study in Western Kenya suggested that the ability of naturally acquired antiPfMSP- $1_{19}$ antibodies to inhibit merozoite invasion in vitro may be a better correlate of clinical immunity to malaria than the mere presence of antibodies measured by conventional ELISA (John et al. 2004). Contrasting with the extensive investigation of the role of Pf MSP- $1_{19}$ in naturally acquired immunity, little is known about the immune recognition of the ortholog protein of $P$. vivax $(\mathrm{Pv})$. In Brazil, high proportions of subjects with detectable antibodies and T-cell responses to PvMSP- $1_{19}$ were found in areas of focal transmission (Soares et al. 1997, 
1999b,c) and high proportions of seropositive subjects were uniformly observed in areas with more stable transmission (Morais et al. 2005).

The prevalence and levels of antibodies to malarial surface antigens such as MSP- $1_{19}$ have been used not only as serological correlates of clinical immunity, but also as markers of cumulative exposure to malaria (Drakeley et al. 2005). Serological data may be particularly useful to infer recent malaria transmission patterns in areas of difficult access, where longitudinal surveys are not logistically feasible. These data presents a potential advantage over traditional parasite prevalence data derived from cross-sectional surveys: the presence of antibodies is thought to reflect recent or cumulative patterns of malaria exposure, rather than current infection, and is therefore less influenced by seasonal variations in malaria transmission rates. A recent study suggested that naturally acquired IgG antibodies to PfMSP- 1 19 performed better than those to other surface antigens (MSP-2 and apical membrane antigen 1) as a marker of malaria transmission intensity in Northern Tanzania, but no attempt was made to compare antibody responses to antigens of other human malaria parasites prevalent in the same area (Drakeley et al. 2005).

Here we explore the use of antibodies to MSP-1 to infer recent patterns of malaria transmission in a remote population in the Amazon Basin of Brazil. We analyze the association between the prevalence of IgG antibodies to PfMSP- $1_{19}$ and PvMSP-1 $1_{19}$, and several putative risk factors for malaria in the population. In addition, we use consecutive seroprevalence data to derive estimates of malaria seroincidence and investigate putative risk factors associated with malaria infections between the cross-sectional surveys.

\section{SUBJECTS, MATERIALS AND METHODS}

Study area and population - The Jaú National Park (JNP) is situated on the right margin of the Negro river, $200 \mathrm{~km}$ Northwest of Manaus, the capital of the state of

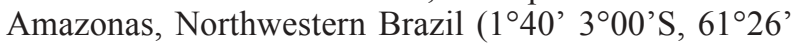
$64^{\circ} 00^{\prime} \mathrm{W}$ ) (Figure). The average annual temperature is between $26^{\circ} \mathrm{C}$ and $27^{\circ} \mathrm{C}$, with an average annual rainfall of 2000-2250 mm; most rainfall occurs between December and April. This is the largest continuous area of protected tropical rainforest in the world (2.27 million hectares). The population, however, is small: 885 inhabitants in 180 dwellings were found in the beginning of the study (November 2002-January 2003), distributed into 30 localities along the Jaú river (12 localities, 40 dwellings, and 225 people), and Unini and Paunini rivers (18 localities, 140 dwellings and 660 people). The population lives in traditional style, on subsistence farming, hunting and fishing, and inhabit wooden dwellings with incomplete or complete walls. Both $P$. vivax and $P$. falciparum are transmitted year-round, with increased incidence at the beginning (August-September), and the end (February-March) of the rainy season. P. vivax predominates in the areas studied. The eligible study population comprised inhabitants in 14 localities ( 8 along the Unini and Paunini rivers and 6 along the Jaú river). The localities of Seringalzinho, Patauá, Capoeira Grande

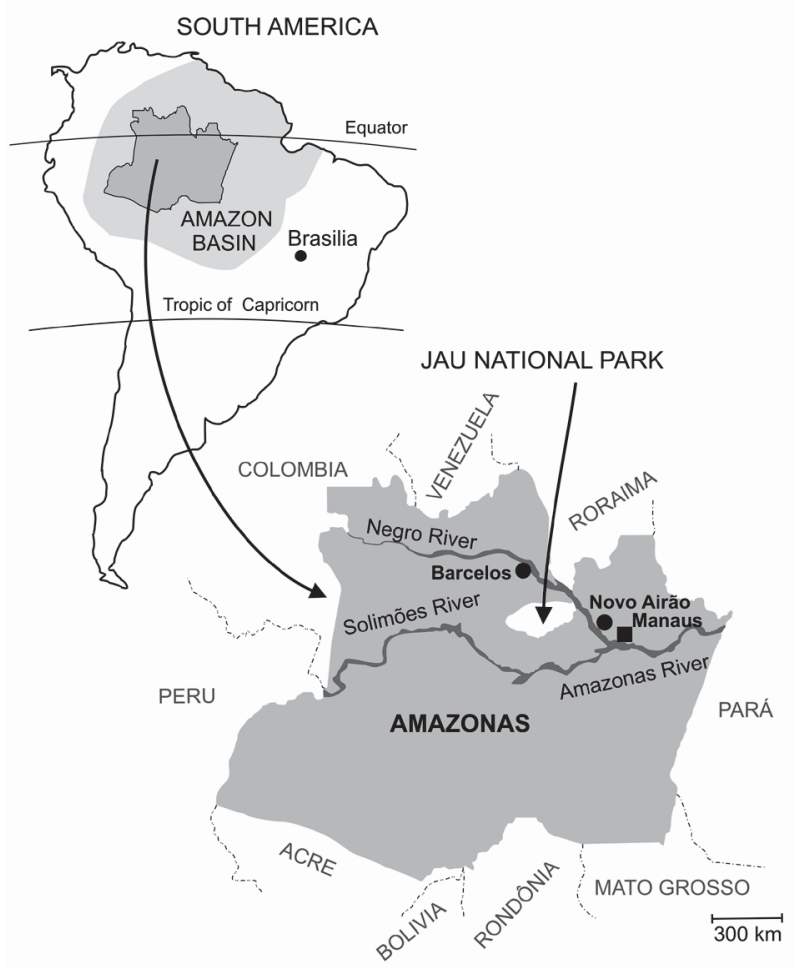

Map of the Amazon Basin, showing the state of Amazonas and the study site, Jaú National Park.

and São Lázaro, Tambor Novo, and Tambor Velho are situated along the lower and upper Jaú river, respectively. The localities of Democracia, Tapiira, Manapana and Lago das Pombas, Floresta, Vista Alegre, Aracú and Solimõezinho are situated along the lower and upper Unini and Paunini rivers, respectively. A detailed structured questionnaire was applied to all study participants to obtain demographic, clinical and behavioural information. The study protocol was approved by the Ethical Committee of the Oswaldo Cruz Institute. All study participants or their guardians provided written informed consent.

Cross-sectional antibody and parasite prevalence surveys - Two cross-sectional surveys (CSS) (1 and 2) were performed during the first travel (A) of the field team to the study site, between November 9, 2002, and January 15,2003 . Survey 1 comprised seven localities along the Unini river and survey 2 comprised three localities along the Jaú river. During the second travel (B), two CSS surveys ( 3 and 4) were performed between May 16 and July 19, 2003. Survey 3 comprised seven localities along the Unini river and one locality along the Paunini river, while survey 4 comprised six localities along the Jaú river. Of 594 residents in the selected localities, 332 (55.9\%) had serum samples tested for antiPvMSP- $1_{19}$ antibodies during travel A (285 in survey 1 and 47 in survey 2), and 480 subjects (80.8\%) in the travel B (318 of the survey 3 and 162 of the survey 4). A total of 283 subjects who had IgG antibodies to PvMSP- $1_{19}$ during both travels $\mathrm{A}$ and $\mathrm{B}$ were included in the $P$. vivax 
seroconversion study. IgG antibodies to PfMSP-1 19 were measured in 331 individuals $(55.7 \%)$ enrolled during travel A (285 in survey 1 and 46 in survey 2), and 473 subjects $(79.6 \%)$ enrolled in travel B (310 in survey 3 and 163 in survey 4). A total of 274 subjects who had IgG antibodies to PfMSP-1 ${ }_{19}$ during both travels A and B were included in the $P$. falciparum seroconversion study. Subjects who were non-permanent residents in the study area, were below three months of age or could not be located during CSSs surveys were excluded from the study.

Malaria diagnosis - Thick blood smears (TBS) from all subjects enrolled in the CSS were stained with Giemsa, and at least 100 fields were examined under 1000' magnification for malaria parasites. Blood samples were also examined by nested polymerase chain reaction (PCR)-based amplification of a species-specific segment of the 18S rRNA gene of human malaria parasites, as described by Kimura et al. (1997) with the modifications introduced by Win et al. (2002). DNA templates for PCR amplification were isolated from $200 \mathrm{ml}$ of whole venous blood using Wizard genomic blood DNA purification kits (Promega, Madison, USA). Three sets of TBS were sent for review by an expert microscopist at the National Reference Laboratory of the Ministry of Health of Brazil: (a) all positive TBS, (b) those with discordant results by TBS and PCR, and (c) 10\% of all negative TBS. All clinical malaria infections diagnosed by onsite microscopy were treated according to the current malaria therapy guidelines in Brazil (Funasa 2001). Because PCR results were not available timely, infections detected by PCR only were left untreated. Results of malaria diagnosis are described in detail elsewhere (Ladeia-Andrade et al. in press).

Recombinant antigens - The recombinant protein PfMSP-1 ${ }_{19}$, which represents the aminoacid sequence of the $19-\mathrm{kDa}$ fragment of MSP-1 of the isolate FVO (Wellcome-type), was expressed in Saccharomyces cerevisae (Kaslow et al. 1994) by David C. Kaslow (currently at Vical Incorporated, San Diego, CA) at the National Institutes of Health, Bethesda, USA. This antigen was kindly supplied for this study. The recombinant PvMSP-1 19 protein corresponds to the aminoacid sequence of the 19-kDa fragment of MSP-1 of the isolate Belém without its hydrophic C-terminus (de Oliveira et al. 1999). This antigen was expressed in Escherichia coli (strain DH10B) as a recombinant protein fused to the C-terminus of Schistosoma japonicum glutathione Stransferase (GST).

Elisa for IgG antibodies - Assays with PfMSP-1 were performed as described (Braga et al. 2002). Highbinding 96-well microplates (Nunc Maxisorp, Denmark) were coated with $50 \mathrm{ng}$ of PfMSP-1 per well, dissolved in $50 \mu \mathrm{l}$ of $0.1 \mathrm{M}$ carbonate-bicarbonate buffer ( $\mathrm{pH} 9.6$ ) and incubated overnight at $4^{\circ} \mathrm{C}$. Serum samples $(50 \mu \mathrm{l} /$ well) were tested at 1:50 dilution (PfMSP-1 ${ }_{19}$ ); these working dilutions were determined by checkerboard titration of positive and negative control sera. IgG antibody binding was detected with peroxidase-conjugated, goat anti-human immunoglobulin (Sigma, St. Louis,
USA) at 1:2,000 dilution. After use of o-phenylenediamine and hydrogen peroxide, absorbance values were measured at $490 \mathrm{~nm}$. The cut-off value was defined as the mean plus three standard deviations of the absorbance values obtained with 40 negative control sera from malaria-naïve blood donors living in Belo Horizonte, Southeastern Brazil. To measure IgG antibodies to PvMSP-1 ${ }_{19}$, high-binding 96well microplates (Costar, Cambridge, USA) were coated with $50 \mathrm{ng} /$ well of solid-phase antigen, dissolved in $50 \mu \mathrm{l}$ of $0.1 \mathrm{M}$ carbonate-bicarbonate buffer ( $\mathrm{pH} 9.6)$, for $18 \mathrm{~h}$ at $4^{\circ} \mathrm{C}$. Serum samples $(50 \mu \mathrm{l} /$ well $)$ were tested at $1: 50$ dilution. After $1 \mathrm{~h}$ incubation at $37^{\circ} \mathrm{C}$, antibody binding to solid-phase antigen was detected with peroxidase-conjugated goat immunoglobulin anti-human IgG (Kirkegaard \& Perry, Gaithersburg, USA) at 1:4,000 dilution. After use of o-phenylenediamine and hydrogen peroxide at acid $\mathrm{pH}$ as substrate, absorbance values were measured as above. Corrected absorbance values were obtained by subtracting absorbance readings with GST run on the same microplate. Absorbance data used in statistical analyses correspond to corrected values. The cutoff absorbance values used to define positive results were 0.228 for $\mathrm{PvMSP}_{19}$ and 0.245 for PfMSP $1_{19}$. These values were calculated as the mean absorbance reading plus three standard deviations (SD) obtained with 40 negative control sera from healthy subjects not exposed to malaria transmission. For both antigens, reactivity indices (RIs) were calculated as the ratio between the absorbance values (corrected values for PvMSP-1 ${ }_{19}$ ) of each test sample and the cut-off value for each antigen. Samples with RIs $\geq 1$ were considered positive.

Definitions - Malaria infection was defined when $P$. vivax or $P$. falciparum were detected by conventional TBS, PCR, or both, irrespective of the presence of symptoms. Serological evidence for malaria infection between two consecutive blood draws was defined when: (a) the first (baseline) sample was IgG-negative but the second sample was IgG-positive, irrespective of the levels of specific antibodies (seroconversion), or (b) there was $\geq 3$-fold increase in IgG levels to either PvMSP-1 ${ }_{19}$ or PfMSP-1 19 (measured as RIs) in paired serum samples collected during travels A and B. We analyzed separately levels of antibodies to PvMSP- $1_{19}$ or PfMSP- $1_{19}$ as markers of recent infection with $P$. vivax and $P$. falciparum, respectively.

Statistical analysis - A database was created with SPSS 13.0 (SPSS Inc, Chicago, USA). Proportions were compared with $\chi^{2}$ tests, with Yates correction of continuity when appropriate. Separate multiple logistic regression models with stepwise backward deletion were built to describe independent associations between potential risk factors (covariates) and the presence of $\mathrm{IgG}$ antibodies to PvMSP-1 19 and PfMSP-1 19 . Because the data have a nested structure, with multiple observations per individual (each study subject participated in one or two cross-sectional surveys), the assumption of independence of observations underlying standard logistic regression analysis is violated. We therefore used twolevel logistic models with robust standard errors, with level-1 variables corresponding to each observation (one 
or two per individual) and level-2 variables corresponding to each individual. Level-1 covariates were age at the time of the survey (continuous variable), date of the cross-sectional survey (travel A or B), recent visit to high-risk areas (stay, in the preceding 30 days, in the forest or in other communities within the JNP with a risk of malaria greater than that in the community of origin), and current malaria infection, while level-2 covariates were gender, place of residence (Unini or Jaú river [residents along the Paunini river were included in the Unini area] and either upper or lower part of the river), use of bednets, sleeping habits (sleeping and wake-up time), bedroom characteristics (presence or absence of complete walls) and customary high-risk activities (hunting, fishing, or bathing close or at the river after 18:00 h). To determine the impact of several covariates on the levels of IgG antibodies to PvMSP- $1_{19}$ and PfMSP- $1_{19}$, we built a two-level multiple linear regression model, with antibody RIs as the outcome variable and the same covariates as above. The HML software package (version 6.03, Scientific Software International, Lincolnwood, USA) was used for all multilevel analyses. Simple logistic regression analysis, carried out with SPSS 13.0, was used to investigate the independent association between recent malaria infection (inferred by seroconversion or increase in antibody levels) and the covariates listed above. Only variables associated with sta- tistical significance at the $5 \%$ level or those that altered the parameter estimate (odds ratio or correlation coefficients) by $\geq 10 \%$ were retained in the final models.

\section{RESULTS}

Prevalence and levels of antibodies to PvMSP-1 19 and PfMSP-1 19 and associated risk factors - IgG antibodies to PvMSP- $1_{19}$ were detected in 231 (69.6\%) subjects aged 10 months to 77 years (mean, 22.2 years) examined during travel $\mathrm{A}$ (middle of rainy season) and in $307(64.0 \%)$ subjects aged six months to 78 years (mean, 23.4 years) examined during travel B (middle of dry season). Unadjusted analysis was carried out separately for each travel. Age, place of residence (Jaú vs. Unini river, upper vs. lower river), absence of complete walls in the bedroom and current infection with $P$. vivax were covariates associated with increased risk of having $\operatorname{IgG}$ antibodies to PvMSP-1 19 , in preliminary unadjusted analysis (Table I). Multilevel logistic regression analysis combining data from both travels showed that the date of the survey (travel A vs. B), place of residence, age, recent visit to high-risk areas and current infection with $P$. vivax were all significant independent predictors of the presence of IgG antibodies to PvMSP-1 19 (Table II). IgG antibodies to PfMSP- ${ }_{19}$ were detected in 172 $(52.0 \%)$ subjects aged 1 to 77 years (mean, 20.5 years) examined during travel A and in 244 (51.6\%) subjects

TABLE I

Prevalence of IgG antibodies to PvMSP-1 19 according to risk factors. Jaú National Park, state of Amazonas, Brazil, 2002-2003

\begin{tabular}{|c|c|c|c|c|c|c|c|c|}
\hline \multirow[b]{2}{*}{ Variable } & \multicolumn{4}{|c|}{ Travel A } & \multicolumn{4}{|c|}{ Travel B } \\
\hline & $\mathrm{n}$ & Prevalence & OR $(95 \% \mathrm{CI})$ & $\mathrm{p}$ & $\mathrm{n}$ & Prevalence & OR $(95 \% \mathrm{CI})$ & $\mathrm{p}$ \\
\hline Age (years) & & & & & & & & \\
\hline $\begin{array}{l}<5 \\
5-10 \\
11-15 \\
16-30 \\
>30\end{array}$ & $\begin{array}{l}63 \\
57 \\
41 \\
86 \\
85\end{array}$ & $\begin{array}{l}65.1 \% \\
68.4 \% \\
70.7 \% \\
59.3 \% \\
83.5 \%\end{array}$ & $\begin{array}{l}1.00 \\
1.16(0.51-2.67) \\
1.30(0.51-3.31) \\
0.78(0.38-1.62) \\
2.72(1.18-6.34)\end{array}$ & $0.086^{a}$ & $\begin{array}{r}84 \\
90 \\
62 \\
121 \\
123\end{array}$ & $\begin{array}{l}58.3 \% \\
54.4 \% \\
71.0 \% \\
57.0 \% \\
78.0 \%\end{array}$ & $\begin{array}{l}1.00 \\
0.85(0.45-1.63) \\
1.75(0.82-3.73) \\
0.95(0.52-1.73) \\
2.54(1.32-4.89)\end{array}$ & $0.0038^{a}$ \\
\hline $\begin{array}{l}\text { Gender } \\
\text { Male } \\
\text { Female }\end{array}$ & $\begin{array}{l}180 \\
152\end{array}$ & $\begin{array}{l}66.7 \% \\
73.0 \%\end{array}$ & $\begin{array}{l}1.00 \\
1.35(0.84-2.17)\end{array}$ & 0.256 & $\begin{array}{l}263 \\
217\end{array}$ & $\begin{array}{l}66.5 \% \\
60.8 \%\end{array}$ & $\begin{array}{l}1.00 \\
0.78(0.54-1.14)\end{array}$ & 0.230 \\
\hline $\begin{array}{l}\text { Place of residence } \\
\text { Unini river } \\
\text { Jaú river }\end{array}$ & $\begin{array}{r}285 \\
47\end{array}$ & $\begin{array}{l}67.4 \% \\
83.0 \%\end{array}$ & $\begin{array}{l}1.00 \\
2.36(1.06-5.26)\end{array}$ & 0.047 & $\begin{array}{l}318 \\
162\end{array}$ & $\begin{array}{l}59.7 \% \\
72.2 \%\end{array}$ & $\begin{array}{l}1.00 \\
1.75(1.16-2.64)\end{array}$ & 0.010 \\
\hline $\begin{array}{l}\text { Place of residence } \\
\text { Lower river } \\
\text { Upper river }\end{array}$ & $\begin{array}{l}166 \\
166\end{array}$ & $\begin{array}{l}60.2 \% \\
78.9 \%\end{array}$ & $\begin{array}{l}1.00 \\
2.47(1.52-4.01)\end{array}$ & 0.000 & $\begin{array}{l}213 \\
267\end{array}$ & $\begin{array}{l}55.4 \% \\
70.8 \%\end{array}$ & $\begin{array}{l}1.00 \\
1.95(1.34-2.85)\end{array}$ & 0.001 \\
\hline $\begin{array}{l}\text { Bedroom walls } \\
\text { Incomplete } \\
\text { Complete }\end{array}$ & $\begin{array}{l}170 \\
162\end{array}$ & $\begin{array}{l}76.5 \% \\
62.3 \%\end{array}$ & $\begin{array}{l}1.96(1.19-3.25) \\
1.00\end{array}$ & 0.007 & $\begin{array}{l}304 \\
176\end{array}$ & $\begin{array}{l}68.8 \% \\
55.7 \%\end{array}$ & $\begin{array}{l}1.75(1.17-2.62) \\
1.00\end{array}$ & 0.006 \\
\hline $\begin{array}{l}\text { Bednet use } \\
\text { Yes } \\
\text { No }\end{array}$ & $\begin{array}{r}42 \\
290\end{array}$ & $\begin{array}{l}76.2 \% \\
68.6 \%\end{array}$ & $\begin{array}{l}1.46(0.69-3.10) \\
1.00\end{array}$ & 0.414 & $\begin{array}{l}100 \\
380\end{array}$ & $\begin{array}{l}72.0 \% \\
61.8 \%\end{array}$ & $\begin{array}{l}1.59(0.98-2.57) \\
1.00\end{array}$ & 0.077 \\
\hline $\begin{array}{l}\text { Sleeping time } \\
\text { Before } 21: 00 \mathrm{~h} \\
\text { At } 21: 00 \mathrm{~h} \text { or later }\end{array}$ & $\begin{array}{l}160 \\
172 \\
\end{array}$ & $\begin{array}{l}73.8 \% \\
65.7 \% \\
\end{array}$ & $\begin{array}{l}1.47(0.89-2.42) \\
1.00\end{array}$ & 0.140 & $\begin{array}{l}295 \\
185 \\
\end{array}$ & $\begin{array}{l}67.5 \% \\
58.4 \% \\
\end{array}$ & $\begin{array}{l}1.48(0.99-2.20) \\
1.00\end{array}$ & 0.055 \\
\hline
\end{tabular}


Travel A

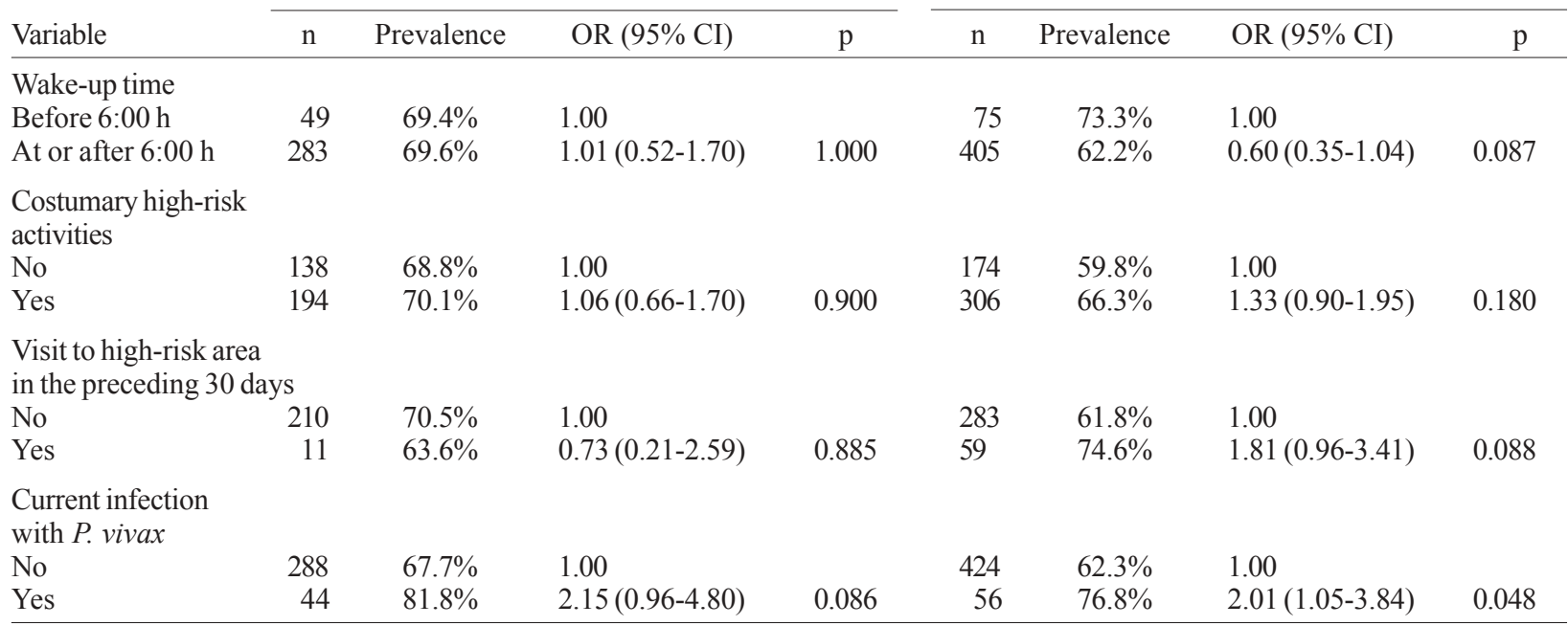

$a$ : $\mathrm{p}$ values of $\chi^{2}$ tests for linear trend (all other $\mathrm{p}$ values are for standard $\chi^{2}$ or Fisher exact tests); $95 \%$ CI: 95\% confidence interval; $\mathrm{n}$ : number of subjects; OR: odds ratio.

TABLE II

Results of the final multilevel logistic regression model including variables significantly associated with IgG antibodies to PvMSP-1 19 and PfMSP-1 19 . Jaú National Park, state of Amazonas, Brazil, 2002-2003

\begin{tabular}{llcc}
\hline Variable & OR & $95 \%$ CI & p value \\
\hline Outcome: IgG antibodies to PvMSP-1 19 & & & \\
$\quad$ Travel (B vs. A) & 0.61 & $(0.43-0.86)$ & 0.005 \\
Place of residence (Jaú vs. Unini river) & 1.91 & $(1.34-3.22)$ & 0.016 \\
$\quad$ Place of residence (upper vs. lower river) & 2.15 & $(1.02-1.06)$ & 0.002 \\
Age (continuous variable) & 1.04 & $(1.02-3.14)$ & 0.0001 \\
Recent visit to high-risk area (yes vs. no) & 1.79 & $(1.33-4.39)$ & 0.043 \\
Current infection with P.vivax (yes vs. no) & 2.42 & & $<0.0001$ \\
Outcome: IgG antibodies to PfMSP-1 19 & & $(1.019-1.06)$ & \\
$\quad$ Age (continuous variable) & 1.04 & &
\end{tabular}

OR: odds ratio; $95 \%$ CI: $95 \%$ confidence interval.

aged six months to 76 years (mean, 26.4 years) examined during travel B. Age, place of residence (Jaú vs. Unini river, upper vs. lower river), use of bednets, sleeping time at 21:00 h or later and reported customary highrisk activities (hunting, fishing, or bathing close or at the river after 18:00 h) were covariates associated with an increased risk of IgG seropositivity to PfMSP- ${ }_{19}$, in preliminary unadjusted analysis (Table III). However, age was the only variable that remained significantly associated with PfMSP-1 ${ }_{19}$ seropositivity in multilevel logistic regression analysis (Table II). Serological data, therefore, proved more useful for inferring risk factors for exposure to $P$. vivax, when compared to $P$. falciparum. In addition, multiple multilevel linear regression models were built to identify covariates independently associated with the levels of IgG antibodies to PvMSP-1 19 and PfMSP-1 19 . Age and current infection with $P$. vivax were significantly associated with increased levels of IgG antibodies to PvMSP- $1_{19}$ ( $\beta$ coefficient $=0.038$ and $0.942 ; p<0.0001$ and 0.006 , respectively), while age was the only covariate significantly associated with increased levels of antibodies to PfMSP- $1_{19}$ ( $\beta$ coefficient $=0.025 ; \mathrm{p}<0.0001)$.

Serological evidence of malaria infection between cross-sectional surveys and associated risk factors Seroconversion or increase in the levels of IgG antibodies to PvMSP-1 ${ }_{19}$ between the first and the second blood draws was observed in 40 of 283 (14.1\%) subjects examined during both travels. Unadjusted analysis suggested that both place of residence (lower vs. upper river) and sleeping time at or after 21:00 h were associated with serological evidence of $P$. vivax infection between the 
TABLE III

Prevalence of IgG antibodies to PfMSP-1 19 according to risk factors in Jaú National Park, state of Amazonas, Brazil, 2002-2003

\begin{tabular}{|c|c|c|c|c|c|c|c|c|}
\hline \multirow[b]{2}{*}{ Variable } & \multicolumn{4}{|c|}{ Travel A } & \multicolumn{4}{|c|}{ Travel B } \\
\hline & $\mathrm{n}$ & Prevalence & OR $(95 \% \mathrm{CI})$ & $\mathrm{p}$ & $\mathrm{n}$ & Prevalence & OR $(95 \%$ CI $)$ & $\mathrm{p}$ \\
\hline \multicolumn{9}{|l|}{ Age (years) } \\
\hline$<5$ & 64 & $31.3 \%$ & 1.00 & & 80 & $22.5 \%$ & 1.00 & \\
\hline $5-10$ & 57 & $31.6 \%$ & $1.02(0.44-2.35)$ & & 91 & $33.0 \%$ & $1.69(0.81-3.55)$ & \\
\hline $11-15$ & 41 & $36.6 \%$ & $1.27(0.51-3.14)$ & & 61 & $47.5 \%$ & $3.12(1.42-6.90)$ & \\
\hline $16-30$ & 86 & $58.1 \%$ & $3.06(1.47-6.40)$ & & 122 & $69.7 \%$ & $7.91(3.94-16.06)$ & \\
\hline$>30$ & 83 & $83.1 \%$ & $10.84(4.65-25.71)$ & $<0.00001^{a}$ & 119 & $68.9 \%$ & $7.63(3.79-15.51)$ & $<0.00001^{a}$ \\
\hline \multicolumn{9}{|l|}{ Gender } \\
\hline Male & 180 & $52.8 \%$ & 1.00 & & 260 & $50.4 \%$ & 1.00 & \\
\hline Female & 151 & $51.0 \%$ & $0.93(0.60-1.44)$ & 0.831 & 213 & $53.1 \%$ & $1.11(0.77-1.60)$ & 0.628 \\
\hline \multicolumn{9}{|l|}{ Place of residence } \\
\hline Unini river & 285 & $51.2 \%$ & 1.00 & & 310 & $55.8 \%$ & 1.00 & \\
\hline Jaú river & 46 & $56.5 \%$ & $1.24(0.66-2.32)$ & 0.612 & 163 & $43.6 \%$ & $0.61(0.42-0.90)$ & 0.015 \\
\hline \multicolumn{9}{|l|}{ Place of residence } \\
\hline Lower river & 166 & $46.4 \%$ & 1.00 & & 209 & $45.9 \%$ & 1.00 & \\
\hline Upper river & 165 & $57.6 \%$ & $1.57(1.02-2.42)$ & 0.054 & 264 & $56.1 \%$ & $1.50(1.04-2.16)$ & 0.036 \\
\hline \multicolumn{9}{|l|}{ Bedroom walls } \\
\hline Incomplete & 169 & $54.4 \%$ & $1.22(0.78-1.93)$ & 0.418 & 301 & $54.2 \%$ & $1.33(0.90-1.97)$ & 0.167 \\
\hline Complete & 162 & $49.4 \%$ & 1.00 & & 172 & $47.1 \%$ & 1.00 & \\
\hline \multicolumn{9}{|l|}{ Bednet use } \\
\hline Yes & 43 & $72.1 \%$ & $2.69(1.33-5.45)$ & 0.008 & 99 & $41.4 \%$ & $0.60(0.38-0.93)$ & 0.030 \\
\hline No & 288 & $49.0 \%$ & 1.00 & & 374 & $54.3 \%$ & 1.00 & \\
\hline \multicolumn{9}{|l|}{ Sleeping time } \\
\hline Before $21: 00 \mathrm{~h}$ & 160 & $43.8 \%$ & $0.53(0.33-0.83)$ & 0.005 & 293 & $42.3 \%$ & $0.37(0.24-0.55)$ & 0.000 \\
\hline At $21: 00 \mathrm{~h}$ or later & 171 & $59.6 \%$ & 1.00 & & 180 & $66.7 \%$ & 1.00 & \\
\hline \multicolumn{9}{|l|}{ Wake-up time } \\
\hline Before 6:00 h & 49 & $61.2 \%$ & 1.00 & & 72 & $55.6 \%$ & 1.00 & \\
\hline At $6: 00 \mathrm{~h}$ or later & 282 & $50.4 \%$ & $0.64(0.35-1.19)$ & 0.211 & 401 & $50.9 \%$ & $0.83(0.50-1.37)$ & 0.546 \\
\hline \multicolumn{9}{|l|}{$\begin{array}{l}\text { Costumary high-risk } \\
\text { activities }\end{array}$} \\
\hline No & 139 & $41.7 \%$ & 1.00 & & 171 & $46.2 \%$ & 1.00 & \\
\hline Yes & 192 & $59.4 \%$ & $2.04(1.31-3.18)$ & 0.002 & 302 & $54.6 \%$ & $1.40(0.96-2.04)$ & 0.095 \\
\hline \multicolumn{9}{|c|}{$\begin{array}{l}\text { Visit to high-risk area } \\
\text { in the preceding } 30 \text { days }\end{array}$} \\
\hline No & 211 & $55.0 \%$ & 1.00 & & 279 & $51.6 \%$ & 1.00 & \\
\hline Yes & 11 & $54.5 \%$ & $0.98(0.29-3.32)$ & 1.000 & 59 & $59.3 \%$ & $1.37(0.77-2.42)$ & 0.350 \\
\hline \multicolumn{9}{|l|}{$\begin{array}{l}\text { Current infection } \\
\text { with P.falciparum }\end{array}$} \\
\hline No & 310 & $51.9 \%$ & 1.00 & & 462 & $51.7 \%$ & 1.00 & \\
\hline Yes & 21 & $52.4 \%$ & $1.02(0.42-2.47)$ & 1.000 & 11 & $45.5 \%$ & $0.78(2.23-2.58)$ & 0.915 \\
\hline
\end{tabular}

$a$ : $\mathrm{p}$ values of $\chi^{2}$ tests for linear trend (all other $\mathrm{p}$ values are for standard $\chi^{2}$ or Fisher exact tests); $95 \%$ CI: $95 \%$ confidence interval; n: number of subjects; OR: odds ratio.

cross-sectional surveys (Table IV), but only the first covariate remained significantly associated with recent $P$. vivax infection after adjusting for potential confounders in multiple logistic regression analysis (lower vs. upper river, odds ratio $=2.52,95 \%$ confidence interval $=1.20-5.32, p=0.015)$. Seroconversion or increase in the levels of antibodies to PfMSP- $1_{19}$ was found in 53 of $274(19.3 \%)$ subjects. Unadjusted analysis suggested that customary high-risk activities would be an independent predictor of recent P. falciparum infection (Table IV), but this was not confirmed after adjustment for potential confounders by multiple logistic regression analysis.

\section{DISCUSSION}

Here we investigated whether naturally acquired IgG antibody response to the conserved $\mathrm{C}$-terminal region of MSP-1 of both $P$. vivax and P. falciparum could provide insights into the epidemiology of malaria in remote populations of the Amazon Basin of Brazil. We found high proportions of subjects who recognized PvMSP-1 19 
TABLE IV

Proportion of subjects who seroconveted against PvMSP- $1_{19}$ and PfMSP- $1_{19}$ during the follow-up, according to risk factors in Jaú National Park, state of Amazonas, Brazil, 2002-2003

\begin{tabular}{|c|c|c|c|c|c|c|c|c|}
\hline \multirow[b]{2}{*}{ Variable } & \multicolumn{4}{|c|}{ IgG antibodie to PvMSP- ${ }_{19}$} & \multicolumn{4}{|c|}{ IgG antibodie to PfMSP- ${ }_{19}$} \\
\hline & $\mathrm{n}$ & $\begin{array}{c}\text { Proportion of } \\
\text { seroconverters }\end{array}$ & OR $(95 \% \mathrm{CI})$ & $\mathrm{p}$ & $\mathrm{n}$ & $\begin{array}{c}\text { Proportion of } \\
\text { seroconverters }\end{array}$ & OR $(95 \% \mathrm{CI})$ & $\mathrm{p}$ \\
\hline \multicolumn{9}{|l|}{ Age (years) } \\
\hline$<5$ & 51 & $15.7 \%$ & 1.00 & & 49 & $18.4 \%$ & 1.00 & \\
\hline $5-10$ & 51 & $5.9 \%$ & $0.34(0.07-1.52)$ & & 51 & $9.8 \%$ & $0.48(0.13-1.76)$ & \\
\hline $11-15$ & 33 & $12.1 \%$ & $0.74(0.17-3.08)$ & & 32 & $31.3 \%$ & $2.02(0.64-6.48)$ & \\
\hline $16-30$ & 69 & $24.6 \%$ & $1.76(0.64-4.96)$ & & 69 & $31.9 \%$ & $2.08(0.80-5.54)$ & \\
\hline$>30$ & 79 & $10.1 \%$ & $0.61(0.19-1.94)$ & $0.648^{a}$ & 73 & $9.6 \%$ & $0.47(0.14-1.52)$ & $0.981^{a}$ \\
\hline \multicolumn{9}{|l|}{ Gender } \\
\hline Male & 153 & $17.0 \%$ & 1.00 & & 147 & $19.0 \%$ & 1.00 & \\
\hline Female & 130 & $10.8 \%$ & $0.59(0.29-1.18)$ & 0.185 & 127 & $19.7 \%$ & $1.04(0.57-1.90)$ & 1.000 \\
\hline \multicolumn{9}{|l|}{ Place of residence } \\
\hline Unini river & 238 & $15.5 \%$ & $2.58(0.72-11.01)$ & 0.182 & 230 & $20.0 \%$ & $1.32(0.52-3.48)$ & 0.674 \\
\hline Jaú river & 45 & $6.7 \%$ & 1.00 & & 44 & $15.9 \%$ & 1.00 & \\
\hline \multicolumn{9}{|l|}{ Place of residence } \\
\hline Lower river & 152 & $19.1 \%$ & $2.57(1.17-5.76)$ & 0.016 & 149 & $18.1 \%$ & $0.84(0.44-1.60)$ & 0.685 \\
\hline Upper river & 131 & $8.4 \%$ & 1.00 & & 125 & $20.8 \%$ & 1.00 & \\
\hline \multicolumn{9}{|l|}{ Bedroom walls } \\
\hline Incomplete & 133 & $10.5 \%$ & $0.56(0.28-1.13)$ & 0.142 & 126 & $19.8 \%$ & $1.06(0.58-1.93)$ & 0.969 \\
\hline Complete & 150 & $17.3 \%$ & 1.00 & & 148 & $18.9 \%$ & 1.00 & \\
\hline \multicolumn{9}{|l|}{ Bednet use } \\
\hline Yes & 36 & $11.1 \%$ & 1.00 & & 36 & $13.9 \%$ & 1.00 & \\
\hline No & 247 & $14.6 \%$ & $1.36(0.43-4.85)$ & 0.763 & 238 & $20.2 \%$ & $1.57(0.54-4.86)$ & 0.508 \\
\hline \multicolumn{9}{|l|}{ Sleeping time } \\
\hline Before 21:00 h & 234 & $12.8 \%$ & 1.00 & & 228 & $18.9 \%$ & 1.00 & \\
\hline At $21: 00 \mathrm{~h}$ or later & 49 & $20.4 \%$ & $1.74(0.73-4.09)$ & 0.246 & 46 & $21.7 \%$ & $1.20(0.51-2.74)$ & 0.805 \\
\hline \multicolumn{9}{|l|}{ Wake-up time } \\
\hline Before $6: 00 \mathrm{~h}$ & 48 & $27.1 \%$ & 1.00 & & 46 & $15.2 \%$ & 1.00 & \\
\hline At $6: 00 \mathrm{~h}$ or later & 235 & $11.5 \%$ & $0.35(0.17-0.74)$ & 0.009 & 228 & $20.2 \%$ & $1.41(0.59-3.35)$ & 0.567 \\
\hline \multicolumn{9}{|l|}{$\begin{array}{l}\text { Costumary high } \\
\text { risk activities }\end{array}$} \\
\hline No & 122 & $13.1 \%$ & 1.00 & & 118 & $26.3 \%$ & 1.00 & \\
\hline Yes & 161 & $14.9 \%$ & $1.16(0.59-2.29)$ & 0.789 & 156 & $14.1 \%$ & $0.46(0.25-0.85)$ & 0.018 \\
\hline
\end{tabular}

$a: \mathrm{p}$ values of $\chi^{2}$ tests for linear trend; $b$ : $\mathrm{p}$ values of Fisher exact tests (all other $\mathrm{p}$ values are for standard $\chi^{2}$ ); $95 \%$ CI: 95\% confidence interval; n: number of subjects; OR: odds ratio.

and PfMSP-1 19 , with no difference according to gender. The proportion of subjects with antibodies to PvMSP-1 19 was associated with age, place of residence and involvement in high-risk activities, defining groups of highly exposed people who might be preferential targets of malaria control measures. In contrast, no risk factor other than age was significantly associated with seropositivity to PfMSP-1 in our subjects.

Serological data have been modeled to estimate medium- and long-term patterns of malaria transmission in areas of Africa (Drakeley et al. 2005), Asia (Gatton et al. 1996), and the Amazon (Burattini et al. 1993) for which accurate estimates of parasite prevalence rates over several years and decades are not available. We next discuss the extent to which serological data correlate with the classical malariometric indices and morbidity indicators measured in our population at the time of the seroprevalence surveys.

Young age, residence along the Unini river, residence in the upper part of either Unini or Jaú rivers, wake-up time after 6:00 $\mathrm{h}$ and absence of complete walls in the bedroom were all significant independent predictors of the presence of malarial parasites, irrespective of the species, detected by either microscopy, PCR or both 
during the CSS in JNP (Ladeia-Andrade et al. in press). Interestingly, the female gender was significantly associated with reduced risk of $P$. vivax infection (confirmed by TBS or PCR) but increased risk of $P$. falciparum infection (Ladeia-Andrade et al. in press). The reason for this is currently unknown.

Subclinical infections and subpatent parasitaemias, which were detected only by PCR, were found in all age groups, but the proportion of infections that are symptomatic was highest among children under five years of age (Ladeia-Andrade et al. in press). As a result, parasite prevalence data revealed that the native Amazonian populations in JNP share some epidemiological features with those living in rural holoendemic Africa, such as the widespread occurrence of subclinical infections and subpatent parasitaemias and predominance of malaria morbidity among young children. These features would have been missed by analyses restricted to serological data, which are unable to reveal age-related differences in current malaria exposure and morbidity.

One of the main limitations of parasite prevalence data obtained during CSS in JNP is that, for logistical reasons, no survey was performed during the peaks of malaria transmission, which typically occur at the beginning (August-September) and the end (FebruaryMarch) of the rainy season. We thus investigated whether a comparative analysis of IgG antibody levels in sequential serum samples could provide estimates of malaria incidence and associated risk factors during the period between the first (November-January) and the second (May-July) CSS, which comprised one of the malaria transmission peaks. However, the analysis of antibody levels in paired samples proved little informative, since we have documented few instances of seroconversion or three fold of greater increase in antibody levels (14.1\% and $19.3 \%$ of the subjects tested for antibodies to PvMSP- ${ }_{19}$ and PfMSP- ${ }_{19}$ in consecutive surveys).The only covariate significantly associated with seroconversion or increase in antibody levels to PvMSP- $1_{19}$ was the place of residence (lower vs. upper river), and no significant predictor of seroconversion in or increase antibody levels to PfMSP- $1_{19}$ was found. The absence of association between recent exposure to malaria (as inferred by comparing antibody levels in paired samples), and age is particularly surprising, since young children have been shown to be at increased risk of laboratory-confirmed infection during the cross-sectional surveys (LadeiaAndrade et al. in press).

This study highlights some limitations of the use of malaria seroprevalence data for epidemiological inference. Although medium- and long-term trends of malaria transmission may be estimated by fitting relatively simple models to serological data (Burattini et al. 1993, Gatton et al. 1996, Drakeley et al. 2005), some epidemiological characteristics that are relevant for malaria control, such as the age-related distribution of infection and morbidity, may be much more difficult to infer without reference to parasite prevalence data. The combined use of classical malariometric and serological data provides clearly complementary information, which may be used to understand malaria transmission patterns, identify risk groups and propose evidence-based control measures.

\section{ACKNOWLEDGEMENTS}

To the inhabitants of Jaú National Park for their enthusiastic participation in the study; Vitória Amazônica Foundation (FVA), Brazilian Institute of the Environment and Natural Resources (IBAMA) for granting access of the research team to JNP; Health Department of Barcelos and the malaria control teams of Barcelos and Novo Airão for help with fieldwork; Deise L Oliveira, Patrícia P Martins, Laura Cristina Santos, Patrícia C Escobar from Fiocruz and Dr Rosely S Malafronte, Mayra N Nassar, and Adriana Y Maeda from Institute of Tropical Medicine of São Paulo for help with PCRbased malaria diagnosis; Francisco das Chagas O Luz (Ministry of Health of Brazil) for reviewing all malaria slides; Cassiano P Nunes (University of São Paulo) for artwork.

\section{REFERENCES}

Blackman MJ, Heidrich HG, Donachie S, McBride JS, Holder AA 1990. A single fragment of a malaria merozoite surface protein remains on the parasite during red cell invasion and is the target of invasion-inhibiting antibodies. J Exp Med 172: 379-382.

Blackman MJ, Ling IT, Nicholls SC, Holder AA 1991. Proteolytic processing of the Plasmodium falciparum merozoites surface protein-1 produces a membrane-bound fragment containing two epidermal growth factor-like domains. Mol Biochem Parasitol 49: 29-34.

Braga EM, Barros RM, Reis TA, Fontes CJ, Morais CG, Martins MS, Krettli AU 2002. Association of the IgG response to Plasmodium falciparum merozoite protein (C-terminal 19 $\mathrm{kD})$ with clinical immunity to malaria in the Brazilian Amazon region. Am J Trop Med Hyg 66: 461-466.

Branch OL, Oloo AJ, Nahlen BL, Kaslow D, Lal AA 2000. Antimerozoite surface protein-1 19-kDa IgG in mother-infant pairs naturally exposed to Plasmodium falciparum: subclass analysis with age. V. The Asembo Bay Cohort Project. $J$ Infect Dis 181: 1746-1752.

Burattini MN, Massad E, Coutinho FA 1993. Malaria transmission rates estimated from serological data. Epidemiol Infect 111: 503-523.

de Oliveira CI, Wunderlich G, Levitus G, Soares IS, Rodrigues MM, Tsuji M, del Portillo HA 1999. Antigenic properties of the merozoite surface protein 1 gene of Plasmodium vivax. Vaccine 17: 2959-2968.

del Portillo HA, Longacre S, Khouri E, David P 1991. Primary structure of the merozoite surface antigen 1 of Plasmodium vivax reveals sequences conserved between different Plasmodium species. Proc Natl Acad Sci USA 88: 4033-4034.

Dodoo DT, Theander T, Kurtzals J, Koram K, Riley E, Akanmori BD, Nkrumah F, Hviid L 1999. Levels of antibody to conserved parts of Plasmodium falciparum merozoite surface protein-1 in Ghanaian children not associated with protection from clinical malaria. Infect Immun 67: 2131-2137.

Drakeley CJ, Corran PH, Coleman PG, Tongren JE, McDonald SLR, Carneiro I, Malima R, Lusingu J, Manjurano A, Nkya WMM, Lemnge MM, Cox J, Reyburn H, Riley EM 2005. Estimating medium- and long-term trends in malaria transmission by using serological markers of malaria exposure. Proc Natl Acad Sci USA 102: 5108-5113.

Egan AF, Morris J, Barnish G, Allen S, Greewood BM, Kaslow DC, Holder AA, Riley EM 1996. Clinical immunity to Plasmodium falciparum malaria is associated with serum anti- 
bodies to the 19-kDa c-terminal fragment of the merozoite surface antigen, PfMSP-1. J Infect Dis 173: 765-769.

Ferreira MU, Ribeiro WL, Tonon AP, Kawamoto F, Rich SM 2003. Sequence diversity and evolution of the malaria vaccine candidate merozoite surface protein-1 (MSP-1) of Plasmodium falciparum. Gene 304: 65-75.

Funasa - Fundação Nacional de Saúde 2001. Manual de Terapêutica da Malária, Brasília, p. 104.

Gatton M, Hogarth W, Saul A, Dayananda P 1996. A model for predicting the transmission rate of malaria from serological data. J Math Biol 34: 878-888.

Han HJ, Park CG, Kim SH, Hwang SY, Jin Han, Traico J, Kho WG, Chung JY 2004. Epidermal growth factor-like motifs 1 and 2 of Plasmodium vivax merozoite surface protein 1 are critical domains in erythrocyte invasion. Biochem Biophys Res Commun 320: 63-570.

John CC, O’Donnell RA, Sumba PO, Moormann AM, KoningWa TF, King CL, Kazura JW, Crabb BS 2004. Evidence that invasion-inhibitory antibodies specific for the $19 \mathrm{kDa}$ fragment of merozoite surface protein-1 (MSP-1 19) can play a protective role against blood-stage Plasmodium falciparum infection in individuals in a malaria endemic area Africa. $J$ Immunol 173: 666-672.

Kaslow DC, Hui G, Kumar S 1994. Expression and antigenicity of Plasmodium falciparum major merozoite surface protein (MSP1 19) variants secreted from Saccharomyces cerevisiae. Mol Biochem Parasitol 63: 283-289.

Kimura M, Kaneko O, Liu Q, Zhou M, Kawamoto F, Wataya Y, Otani S, Yamaguchi Y, Tanabe K 1997. Identification of the four species of human malaria parasites by nested PCR that targets variant sequences in the small subunit rRNA gene. Parasitol Internat 46: 91-95.

Ladeia-Andrade S, Ferreira UM, Carvalho ME, Curado I, Coura JR. Age-dependent acquisition of protective immunity to malaria among riverine populations of the Amazon Basin of Brazil. Trans R Soc Trop Med Hyg (in press).

Miller LH, Roberts T, Shahabuddin M, McCutchan TF 1993. Analysis of sequence diversity in the Plasmodium falciparum merozoite surface protein-1 (MSP-1). Mol Biochem Parasitol 59: 1-14.

Morais CG, Soares IS, Carvalho LH, Fontes CJ, Krettli AU, Braga EM 2005. IgG isotype to C-terminal $19 \mathrm{kDa}$ of Plasmodium vivax merozoite surface protein 1 among subjects with different levels of exposure to malaria in Brazil. Parasitol Res 95: 420-426.

O'Donnell RA, de Koning-Ward TF, Burt RA, Bockarie M, Reeder JC, Cowman AF, Crabb BS 2001. Antibodies against merozoite surface protein (MSP)- $1_{19}$ are a major component of the invasion-inhibitory response in individuals immune to malaria. J Exp Med 193: 1403-1412.

Putaporntip C, Jongwutiwes S, Sakihama N, Ferreira MU, Kho WG, Kaneko A, Kanbara H, Hattori T, Tanabe K 2002. Mosaic organization and heterogeneity in frequency of allelic recombination of the Plasmodium vivax merozoite surface protein-1 locus. Proc Natl Acad Sci USA 99: 16348-16353.

Riley EM, Wagner GE, Ofori MF, Wheeler JG, Akanmori BD, Tetteh K, McGuinness D, Bennett S, Nkrumah FK, Anders RF, Koram KA 2000. Lack of association between maternal antibody and protection of African infants from malaria infection. Infect Immun 68: 5856-5863.

Soares IS, Barnwell JW, Ferreira MU, Da Cunha MG, Laurino JP, Castilho BA, Rodrigues MM 1999a. A Plasmodium vivax vaccine candidate displays limited allele polymorphism, which does not restrict recognition by antibodies. Mol Med 5: 459-470.

Soares IS, Cunha MG, Silva MN, Souza JM, Del Portillo HA, Rodrigues MM 1999b. Longevity of the naturally acquired antibody responses to the $\mathrm{N}$ - and $\mathrm{C}$-terminal regions of Plasmodium vivax MSP1. Am J Trop Med Hyg 60: 357-363.

Soares IS, Levitus G, Souza JM, Del Portillo HA, Rodrigues MM 1997. Acquired immune responses to the $\mathrm{N}$ - and C-terminal regions of Plasmodium vivax merozoite surface protein 1 in individuals exposed to malaria. Infect Immun 65: 1606-1614.

Soares IS, Oliveira SG, Souza JM, Rodrigues MM 1999c. Antibody response to the $\mathrm{N}$ and $\mathrm{C}$-terminal regions of the Merozoite Surface Protein 1 in individuals living in an area of exclusive transmission of Plasmodium vivax malaria in the north of Brazil. Acta Trop 72: 13-24.

Tanabe K, Mackay M, Goman M, Scaife JG 1987. Allelic dimorphism in a surface antigen gene of the malaria parasite Plasmodium falciparum. J Mol Biol 195: 273-283.

Win TT, Lin K, Mizuno S, Zhou M, Liu Q, Ferreira MU, Tantular IS, Komija S, Ishii A, Kawamoto F 2002. Wide distribution of Plasmodium ovale in Myanmar. Trop Med Int Health 7: 231-239. 
